\title{
EVALUATION OF STRATEGIC BUILDING MAINTENANCE AND REFURBISHMENT BUDGETING METHOD SCHROEDER
}

\author{
Markus CHRISTEN ${ }^{\text {a,**, Jules SCHROEDER }}{ }^{\text {b }}$, Holger WALLBAUM ${ }^{\text {a }}$ \\ ${ }^{a}$ Institute of Construction and Infrastructure Management, Swiss Federal Institute of Technology ETH \\ Zurich, Haeldeliweg 15, 8092 Zurich, Switzerland \\ ${ }^{b}$ Retired, former head of property management of the canton of Zurich/Switzerland
}

Received 11 April 2012; accepted 16 September 2013

\begin{abstract}
The method Schroeder is accepted amongst real estate professionals in Switzerland as a near standard for condition monitoring, budgeting of maintenance and refurbishment, and strategic decision support in point of building portfolios. It is based on the devaluation curves of 12 or more building elements. Main results are the actual and the prognosticated future building condition in percentage of its reinstatement value, the residual useful service life of building elements, and the calculation of future maintenance and refurbishment costs. 25 years after its first publication, this paper analyses the assumptions made, compares the method to other methods in this field, and validates the method in several steps, based on scientific or empirical evidence. Furthermore, a desktop simulation of a well-documented portfolio was performed and compared, the answers from a questionnaire amongst users are provided, and the partially controversial conclusions are discussed.
\end{abstract}

KEYWORDS: Strategic property management; Building portfolio; Maintenance and refurbishment budgeting; Method Schroeder; Devaluation curve

\section{INTRODUCTION}

In every economy and organisation, the existing building stock forms an indispensable and major asset which needs to be maintained, improved, and eventually replaced. This requires a measurable part of the gross domestic product (GDP) and therefore has to be performed in an economical manner by optimising between minimal costs and avoiding a maintenance backlog while considering aspects of sustainability. Kohler and Yang (2007) have investigated the long-term behavior of this enormous asset stock in a combination of flow- and capital-based approaches and have discussed strategies to influence it.

As a consequence of the importance of the existing building stock, budgeting of maintenance and refurbishment is a commonplace as well as challenging task for property owners and managers. In an industrial facility, the potential loss of production and the following loss of profitability justify adequate maintenance budgets based on technical considerations, even in tight economic situations.

* Corresponding author. E-mail: christen@ethrat.ch
An extensive range of methods and instruments has been developed to support maintenance in industry. In real estate, it is common practice to postpone maintenance for several years to reduce costs in private organisations or to reduce public spending. Today, maintenance and refurbishment decisions for building portfolios are more based on user requirements and market considerations than on predicted durability of building elements. Consequently, portfolio managers need a strategic instrument which shows the consequences of postponed investments in a portfolio in order to justify the budgets they are demanding. Any method to forecast maintenance and refurbishment costs basically relies on the prediction of durability of single building elements. The British Standard BS 7543 (1992) made a noteworthy statement about this: "Prediction of durability is subject to many variables and cannot be an exact science". This, combined with individual strategic decisions and other context, adds to the complexity of the task. In recent decades, several methods to overcome this complexity were proposed (see Table 3). However, 
there are only a limited number of scientists conducting research in this field, consequently publications and data sets are sparse (see section 4). The existing research gap is considerable in light of the size and age of the building stock.

One method which has proven successful in the property market is the method Schroeder, in form of the respective software application called Stratus (in Switzerland) or Spectus (international). Today, the method is used in 100 portfolios encompassing more than $20^{\prime} 000$ buildings. 25 years after its publication, this paper analyses the assumptions, compares the method to other methods in this field, and validates the method in several steps based on scientific or empirical evidence.

This paper looks at the terminology in maintenance and the basic formulas in chapter 2, describes the Method Schroeder in chapter 3, and in chapter 4 validates and compares the method to other methods in this field in chapter 4 .

\section{FUNDAMENTALS IN BUILDING MAINTENANCE}

\subsection{Maintenance terminology}

The term maintenance has several definitions. The definition in this paper follows the new European Standard in Facility Management EN 15221-4: Taxonomy, Classification and Structures in Facility Management (2012). The standard defines a hierarchically structured set of more than $100 \mathrm{fa}$ - cility products. These products have been designed to allocate costs, to define, compare and improve quality and to enable benchmarking in the support services market. To distinguish between annual costs (expenses in the income statement) and investments (listed as an asset in the balance sheet), the standard allocates the first ones to the product "maintenance" and the second ones to the product "asset replacement and refurbishment". Figure 1 shows the relation between the devaluation curve of an asset and the relevant facility products to describe the curve and its values and costs.

It is important to note that this standard acknowledges the fact that refurbishment not only restores the initial value of an asset but, due to better technology available, very often results in a higher standard. A good example of this regards the replacement of windows. New windows are most certainly better than old ones and at approximately the same, or even lower, costs. It should also be noted that in many organisations the line between maintenance and refurbishment is often drawn based on financial considerations and not on technical definitions, e.g. every measure above a fixed amount/threshold counts as refurbishment and is set up as an asset in the balance sheet. Unfortunately, this threshold is determined at individual levels and within a wide range. This fact adds to the complexity of comparing or benchmarking maintenance costs. Another method to distinguish between maintenance and refurbishment is the maintenance signature presented in section 4 .

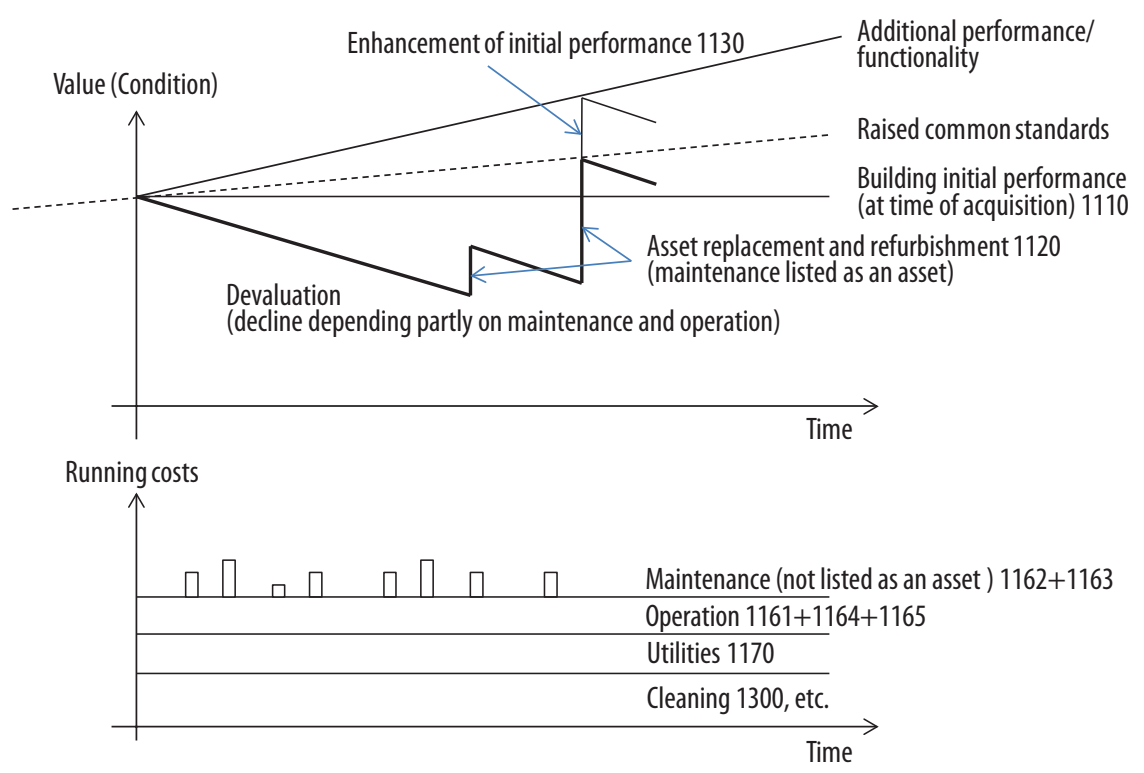

Fig. 1. Relation between maintenance and refurbishment and facility products defined in EN 15221-4 (numbers in the Figure 1 refer to facility products defined in the standard) 


\subsection{Basic formulas to calculate maintenance and refurbishment}

Based on the devaluation model of a building and common knowledge about maintenance and property management, the following formulas are proposed (refer also to Bahr, Lennerts 2010).

Annual maintenance expenses for a building:

$$
E_{m}=E_{t} * F_{s},
$$

where: $E_{m}$ - annual maintenance expenses for a building [\% of $\left.V_{a}\right] ; E_{t}$ - expenses required from a technical point of view (e.g. $1.0 \%$ of $V_{a}$ per annum) [\% of $V_{a}$ ]; $F_{s}$ - factor for strategic decisions influencing maintenance budgets [-].

Methods to estimate annual maintenance expenses usually concentrate on the technical side because of the individual nature of strategic decisions of organisations.

Refurbishment investment for a building at time $t$ :

$$
I_{r b}=V_{a} *\left(1-C_{t}\right) * F_{r} * F_{a},
$$

where: $I_{r b}$ - investment needed to bring a building back to its initial condition [currency]; $V_{a}-$ reinstatement value of the asset or building (also: replacement or insurance value) [currency]; $C_{t}-$ condition of building in \% of $V_{a}$ at time $t$ [\%]; $F_{r}-$ factor to calculate the required investment based on the total devaluation $\left(1-C_{t}\right)$ to bring the building back to its initial value $[-] ; F_{a}$ - factor for additional investment required to achieve added value if required $[-]$.

\section{DESCRIPTION OF METHOD SCHROEDER}

In the mid-1980s Jules Schroeder, a property manager for the canton of Zurich in Switzerland, developed a simple to use method for effective and comprehensible budgeting of maintenance and refurbishment in building portfolios. The initial inhouse application was later commercialised and is continuously being improved upon. However, the method itself has not changed since its first publication.

The method was based on the practical experience gained from more than 2'000 buildings, in combination with scientific research at the Swiss Federal Institute of Technology in Zurich (ETH Zurich) in Meyer-Meierling (2011, first published 1994). At the centre are the devaluation curves of building elements like structure, roof, façade, windows, building technique etc. The choice of elements has been an optimization process between minimization of the effort to collect and maintain data and the need for sufficiently detailed data to provide relevant information. Usually refurbished as a package, 12 to 20 elements were found to be optimal (see Annex 1). The method itself would permit a higher number of elements to be used resulting in higher costs for assessment and data management. The condition of these elements is usually assessed by experts or by trained in-house staff to assure a comparable outcome.

The devaluation curves determine the value or condition of the elements in function of the time. An assessed value from the condition survey, therefore, determines a theoretical age (e.g. independent of effective age or other factors) of the element and, following the depreciation curve, the remaining service life before refurbishment is due. The curve has been given an exponential function $\left(C_{t}=1-t^{a}\right)$ and split into two phases in order to better reflect the empirical data (formulas $3+$ 4). The empirical functions for different elements have been validated within IP Bau (1991), a government research program, based on a detailed examination of a portfolio containing 120 buildings. The formulas for the two phases of the devaluation curves (Fig. 2) in the method Schroeder are as follows:

$$
\text { Condition Phase 1: } C_{t}=1-t_{p}\left(\frac{1}{t_{p}}\right)^{a 1}
$$

in Schroeder (1989),

Condition Phase 2:

$$
C_{t}=C_{t p}-\left(\frac{C_{t p}\left(t-t_{p}\right)}{C_{t p}}\right)^{a 2}
$$

in Schroeder (1989),

where: $t_{p}$ - time where phase 1 ends and phase 2 begins [years]; $C_{t p}-$ condition $C_{t}$ at time $t_{p}$ where phase 1 ends and phase 2 begins [\%]; $a_{1}, a_{2}$ - exponents determining the form of the devaluation curves in phases 1 and $2[-]$.

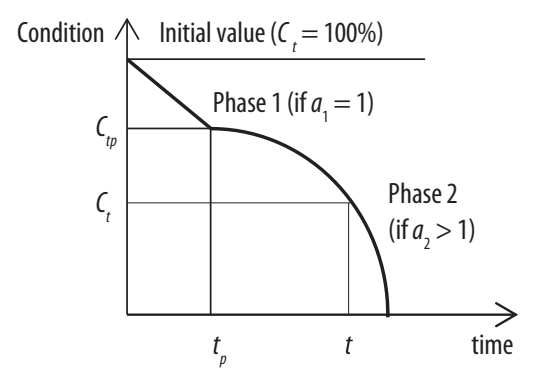

Fig. 2. Exemplary model of devaluation curve of a building element with two phases as a condition-time diagram 
After the condition has been surveyed on site, the remaining service life of an element or building is determined with the help of the devaluation curves. The next question is: how much does it cost to refurbish an element, or building at a given point in time, and when is it best to perform this task? Of course it would be great if it were possible to only measure the difference between the actual value $C_{t^{*}} V_{a}$ and the initial reinstatement value $V_{a}$ to determine the investment needed for refurbishment $I_{r}$. Based on experience, the method Schroeder suggests that this is not so easy. Elements must often be replaced as a whole, not in parts, which means that premature replacement costs more than the calculated depreciation or devaluation. To replace an element often costs more than its initial construction due to additional costs for e.g. scaffolding, adjustments to adjacent elements or accommodation of users during construction work. So, even at maturity, the costs may be a factor higher than the simple difference mentioned above. In order to solve the problem the method Schroeder (1989) uses a refurbishment factor $F_{r}(5)$, which depends on the condition $C_{t}$ of the building element for the calculation of the required investments.

$$
\text { Refurbishment factor: } F_{r}=1+\frac{C_{t}}{\left(1-C_{t p}\right)} \text {, }
$$

in Schroeder (1989),

where: $F_{r}$ - condition dependent factor to calculate the investment needed to bring a building element back to its initial value $[-]$.

The factor $F_{r}$ may depend on additional factors like type of building, ambient conditions or occupation as shown by Lavy and Shohet (2007). The soft- ware application offers possibilities for individual adjustments for each building and element. These possibilities were not part of the original method Schroeder.

Annual maintenance on the other hand is modelled as an exponential function of $C_{t}$ between around $0.5 \%$ (at $C_{t}=100 \%$ new condition) and $2 \%$ (at $C_{t}=70 \%$ ). At lower conditions, it is assumed that only minimal maintenance is being performed because the object is potentially due to be refurbished or demolished and replaced by a new construction.

The Table 1 lists the required as well as optional input data that the software application Stratus/Spectus (2012) needs to calculate the listed output data. To support the assessment, external assessment services or training of in-house staff is offered by the provider.

Table 1 shows that only minimal input data is needed to calculate the output required for different strategic decisions. In particular, no historical data, which is often unavailable or hidden deeply in some archives, is required. As an option correction factors can be used to incorporate specific knowledge or experience. The condition of each building and therefore the whole portfolio is automatically recalculated each year based on the devaluation curves of the elements. This simulates the effective annual degradation and indicates the dynamic behaviour of the portfolio. Other functions include comparable benchmarking of the overall condition of the portfolio and the bundling of refurbishment works for different buildings in the years to come.

In Figure 3 an example of the representation of an entire portfolio in a sum curve covering all buildings is given.

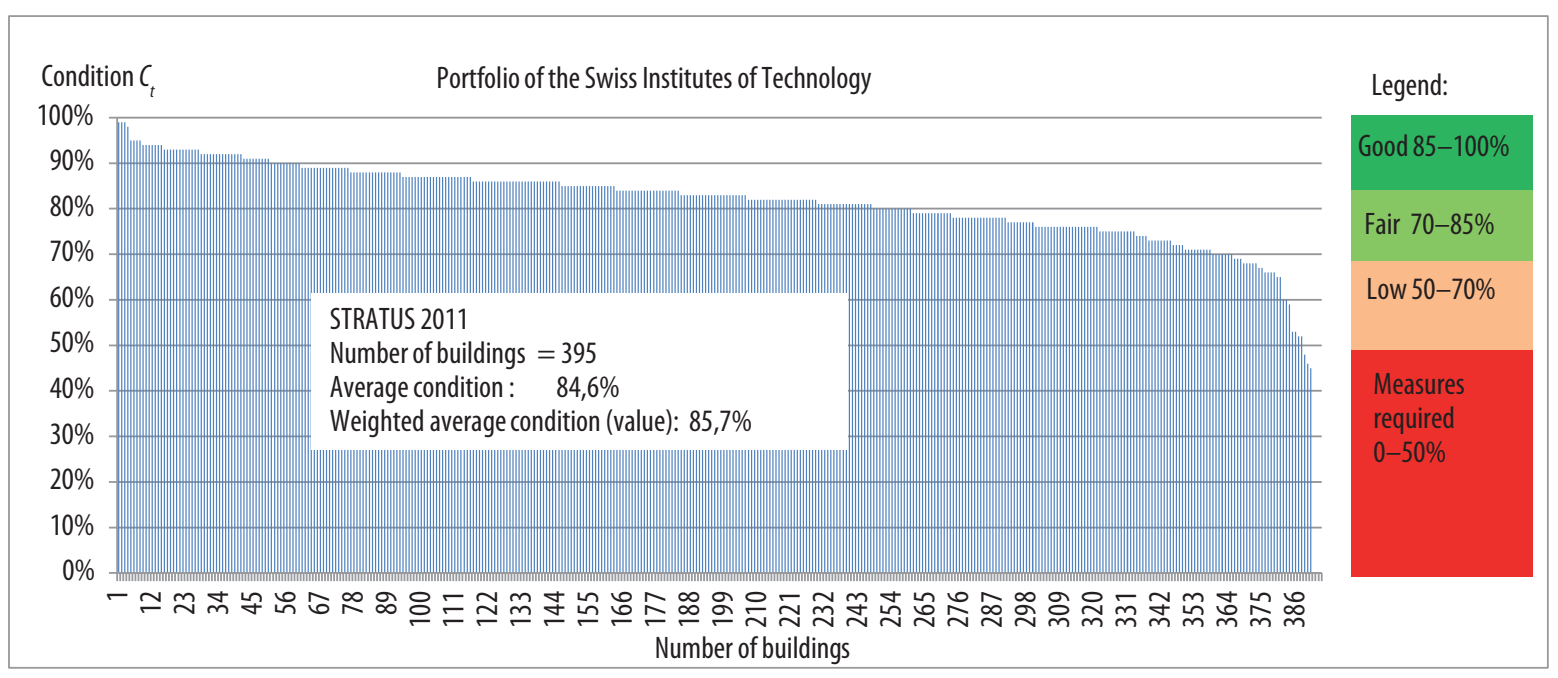

Fig. 3. Typical summation curve of the condition of a portfolio - for those objects below $70 \%$ an object strategy is needed (range of descriptions of condition is based on practical experience) 
Table 1. Required Input and calculated output from the instrument Stratus/Spectus based on the method Schroeder

\begin{tabular}{|c|c|}
\hline Input Data & Remarks/Description \\
\hline Building reinstatement value $V_{a}$ & $\begin{array}{l}\text { Estimated replacement, reinstatement or insurance val- } \\
\text { ue, the value may be corrected manually by the property } \\
\text { manager if needed }\end{array}$ \\
\hline Condition survey of 12 - max. 20 elements & $\begin{array}{l}\text { Standardised and self-explanatory input sheet available, } \\
\text { requires approx. } 1 \text { hour per building }\end{array}$ \\
\hline Volume $\left(\mathrm{m}^{3}\right)$ or area $\left(\mathrm{m}^{2}\right)$ & Whatever is available \\
\hline Construction cost index & $\begin{array}{l}\text { Taking the development of past and future construction } \\
\text { costs into consideration }\end{array}$ \\
\hline $\begin{array}{l}\text { Optional: effective portion of total building costs of the ele- } \\
\text { ments surveyed }\end{array}$ & $\begin{array}{l}\text { Manual correction of standard values for specific build- } \\
\text { ings possible if required }\end{array}$ \\
\hline $\begin{array}{l}\text { Optional: type of building and level of installed building } \\
\text { technique }\end{array}$ & $\begin{array}{l}\text { Influences the choice of building elements especially in } \\
\text { regards to building technique }\end{array}$ \\
\hline $\begin{array}{l}\text { Optional: effective maintenance and refurbishment works } \\
\text { performed }\end{array}$ & $\begin{array}{l}\text { Supports documentation of history of buildings and vali- } \\
\text { dation of factors based on experience }\end{array}$ \\
\hline $\begin{array}{l}\text { Optional: data about energy consumption, earth quake } \\
\text { safety, security, etc. }\end{array}$ & $\begin{array}{l}\text { Depending on questions arising from strategic property } \\
\text { management }\end{array}$ \\
\hline Output Data & Remarks/Description \\
\hline
\end{tabular}

For the entire portfolio

Average condition of portfolio

Change of condition in function of time and performed maintenance and refurbishment

Annual costs for maintenance and investments for refurbishment over a selectable period

Buildings which need refurbishment

Simulation of effects of different maintenance strategies and shifting time of refurbishment works

For a single building

Condition of building in $\%$ of initial value at a given point in time

Annual costs for maintenance over a selectable period/number of years

Investment for refurbishment in a selected year

Refurbishment backlog

Optional: Building energy certificate, assessment of earth quake safety, risk analysis, etc.

For each separately assessed building element

Condition of element

Estimated due time for refurbishment of element

Estimated cost of refurbishment of element in due time
The condition of the portfolio can be presented in form of a summation curve (Fig. 3) for all objects

Annual devaluation (automatically calculated based on the devaluation curves) and maintenance and refurbishment need to be in a balance if the condition is to be kept at the desired level

Main figures to support budgeting

Depending on strategic choices, buildings below $70 \%$, $60 \%$ or even $50 \%$ are visible at a glance in the sum curve and can be selected for detailed planning

Simulation typically covers a period of 25 years, shorter or longer periods are possible

Strategic figure to evaluate the need for more detailed planning and to control the actual value in the accounting system at a selected point in time (e.g. in five or ten years)

Depending on condition $C_{t}$

Depending on condition $C_{t}$

Due costs of elements which are rated to be mature for refurbishment

Required by law in some countries

Based on condition survey and calculated devaluation based on individual curves for each element

Based on individual devaluation curves for each element

Based on condition of the element and its average portion of total building new value 


\section{VALIDATION OF THE METHOD SCHROEDER}

The validation process employed in this paper encompasses several steps, a different approach used in each. It includes state-of-the-art research, questioning the assumptions, comparison with other products, answers of users to a questionnaire to get a feedback from the market, and comparison to data from two real portfolios where effective data is available.

\subsection{State of the review}

In general, more research is conducted in the field of industrial maintenance than that of building maintenance, because of the former's immediate effect on productivity and profitability. Building maintenance is seen as less critical and maintenance practices are usually lagging behind industry (Christen et al. 2011). The method Schroeder is specifically adapted to the longevity of building elements and therefore less suitable to the short life cycles of production machinery.

Zavadskas et al. (2004) compared the average market price of refurbished dwellings and the cost of newly-built dwellings in Vilnius (Lithuania). They found that the market price and, consequently the refurbishment strategy, depend on the area where an object is located in order not to exceed the potential market value.

Bjørberg (2008) conducted an assessment of 10 '000, or $40 \%$ of all public buildings in Norway, in order to identify maintenance strategies and recommend a budget cost level for long term planned maintenance. In each building, 16 elements were graded into four levels to assess the condition. The grading is quite similar to that used in the method Schroeder. He estimates that a portfolio needs to encompass 40-50 different buildings with around 50 '000 $\mathrm{m}^{2}$ to enable a representative estimate of the annual budget for maintenance and refurbishment. This would have to be debated in the light of the findings presented in this paper.

Kumar et al. (2010) identified three principal methods, the probabilistic methods, the engineering methods, and the deterministic methods in order to predict the service life of a building system and their components. Due to the complexity of the other methods, they proposed a deterministic method called capital refurbishment model, which has similarities to the method Schroeder. It uses only six building elements with fixed service life expectancy but spreads the refurbishment costs over a period of 5 years to accommodate variations.
Bahr and Lennerts (2010) compared different maintenance and refurbishment budgeting methods with their findings from a detailed analysis of the costs in 17 buildings over several decades. As part of their findings, they recommend the division between maintenance and refurbishment as found in the method Schroeder and as defined in EN 15221-4. The method Schroeder is represented as propagating a fixed total budget of $1.1 \%$ of the building value and this figure is then compared to the combined, fluctuating costs for maintenance and refurbishment from the detailed analysis. As shown in this paper, the method Schroeder is much more differentiated and accurate.

Based on the results of the analysis of the 17 buildings, Bahr and Lennerts developed a new method called PABI (practical adaptive budgeting of maintenance measures) with a similar formula as to the one stated above (1). The method combines fixed percentages for maintenance $(1.2 \%$, regular measures) and refurbishment (4.4\%, oneoff measures) with correction factors relating to age, wear and tear, materials, etc. The result is a fast estimate of average total annual budgets, but only vague information about the future distribution of the costs in time - each differentiated period covers one decade - or the condition and the need for refurbishment of building elements is provided.

\subsection{Analysis and validation of assumptions in the method Schroeder}

Of the nine assumptions in Table 2, the five assumptions including numbers 1 to 3,5 and 8 , have been validated whereas the other four assumptions are based on empirical evidence. These are likely sufficient for strategic budgeting but more research would be needed for validation. Additional investments to achieve added value (factor $\mathrm{F}_{\mathrm{a}}$ ) are not considered in this method.

\subsection{Comparison with other methods for maintenance budgeting}

Mickaityte et al. (2008) describe in the context of refurbishment and sustainability different methods for maintenance planning. However, many of these are not broadly applied nor used in the market today. Table 3 provides and comments an incomprehensive selection of instruments covering an array of different such methods.

The list of instruments in Table 3 highlights the differences in their focus and application. To put it into perspective, by looking at the focus of 
Table 2. Validation of assumptions the method Schroeder is based upon [units of diagrams]

\begin{tabular}{|c|c|c|c|}
\hline Assumption & Graphic & Empirical evidence & Scientific evidence \\
\hline $\begin{array}{l}\text { 1: Division into mainte- } \\
\text { nance (line) and refur- } \\
\text { bishment (dots) } \\
\text { [costs/time] }\end{array}$ & $\uparrow$ & $\begin{array}{l}\text { The difference between annu- } \\
\text { al expenses and investments } \\
\text { with project character are } \\
\text { also visible in the representa- } \\
\text { tion in the accounting system } \\
\text { of many organisations }\end{array}$ & $\begin{array}{l}\text { Bahr and Lennerts (2010) } \\
\text { stated in their work that } \\
\text { this difference must be } \\
\text { obeyed and created the } \\
\text { method PABI which factors } \\
\text { this differentiation in }\end{array}$ \\
\hline $\begin{array}{l}\text { 2: Non-linear deprecia- } \\
\text { tion or devaluation of } \\
\text { building elements } \\
\text { [condition/time] }\end{array}$ & $\uparrow$ & $\begin{array}{l}\text { The first model using linear } \\
\text { curves did not fit the effec- } \\
\text { tive expenses in the portfolio } \\
\text { the method was originally de- } \\
\text { signed for. }\end{array}$ & $\begin{array}{l}\text { IP Bau (1991) validated the } \\
\text { shape of the curves for the } \\
\text { different elements based } \\
\text { on a detailed survey of } 120 \\
\text { buildings. }\end{array}$ \\
\hline
\end{tabular}

3: Depreciation or devaluation divided into two steps [condition/time]

4: Variable condition based annual maintenance expenses [costs/time]

5: Condition/service-life based time for replacement and refurbishment investments [costs/time]

6: The condition of an element is an indicator of the costs for refurbishment or replacement (investment to restore the initial 100\% condition)

[condition/time]

7: Analysis of actual condition of an element is sufficient, the effective age of an element does not matter (condition/time)

8: Average portion of elements in percentage of total costs is a function of building type [\% of costs]

9: Maintenance strategy influences maintenance intervals
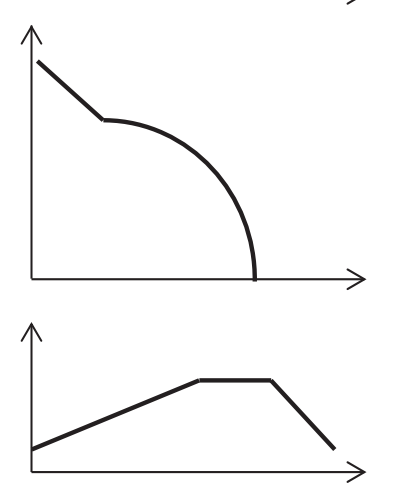

Machines often need some time before they reach stable running conditions. Cracks in buildings usually develop shortly after construction.

New buildings need less caretaking than used ones - in older buildings, often less money is spent for economic reasons.

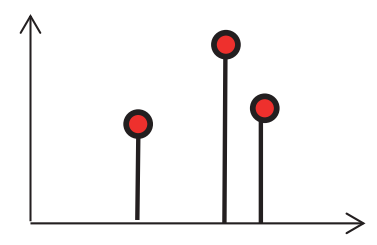

The condition determines the time for replacement and refurbishment of building elements based on their predicted durability or service-life.

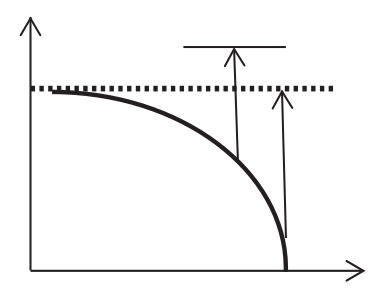

An empirical factor $\left(F_{r}\right)$ as a function of the condition is applied to calculate effects such as whole elements being replaced and additional costs such as scaffolding. $F_{r}$ can be adjusted manually depending on occupancy etc. if required.

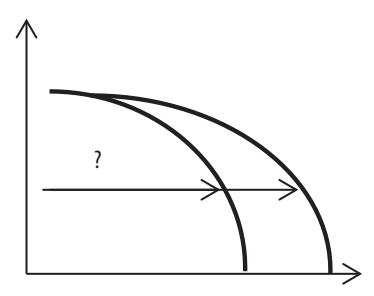

To know age and condition could improve the forecast in the long run. However, the effective age is often not available.

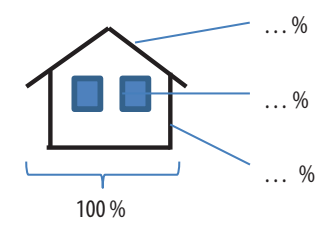

An individual assessment of construction costs for each building requires a large effort.

Graf (2008) has analysed costs of 228 buildings to verify the standard values for different building types.

Empirical factor to take indi- No scientific evidence to vidual strategic decisions into verify this factor was found. account.
IP Bau (1991) validated the shape of the curves. Newer evidence found in Caccavelli et al. (2003) and MeyerMeierling (2011)

Two exemplary portfolios show different results. Further research is needed to verify the assumed function.

The concept of statistical service-life of elements is widely accepted, e.g. in ISO 15686 (2008).

Lavy and Shohet (2007) found dependencies up to $20 \%$ on type of configuration and hence introduced the facility coefficient. Bahr and Lennerts (2010) also found building related factors (e.g. complexity of façade).

A budgeting period usually covers less than 5 years. The additional effort to analyse the age is therefore not required. 
specific instruments and their costs per object, a qualitative rating was performed (Fig. 4).

The rating gives an indication of the application and the required effort of the instruments. It highlights a possible problem in some of them. The deeper they go into detail (e.g. number of elements) the higher the costs per object are. The relation was assumed to be linear. Eventually, the instruments reach the point where they become too expensive for strategic portfolio considerations. For the design of a refurbishment project, organisations prefer to use standard construction and project management tools.

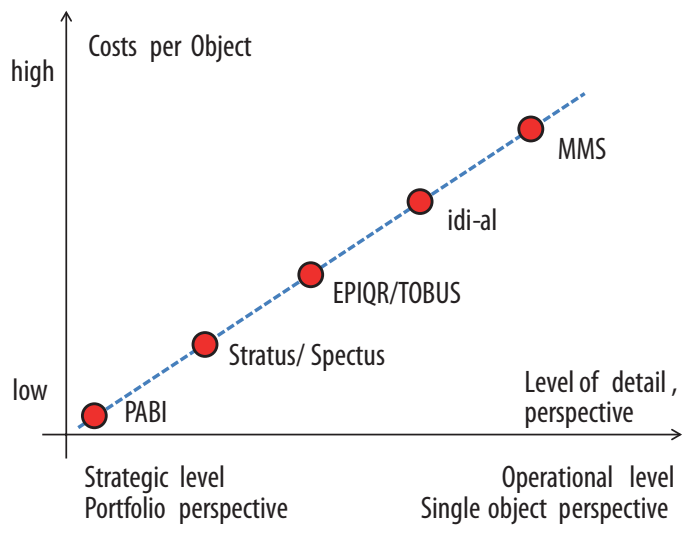

Fig. 4. Qualitative rating of maintenance and refurbishment planning and budgeting instruments

Table 3. Commented list of examples of maintenance budgeting and/or planning methods and instruments

\begin{tabular}{|c|c|c|c|}
\hline Method/Instrument & Focus & Limitations & Application \\
\hline PABI (Bahr, Lennerts 2010) & Portfolio level & $\begin{array}{l}\text { Empirical evidence of correc- } \\
\text { tion factors }\end{array}$ & $\begin{array}{l}\text { Budgeting without on- } \\
\text { site assessment }\end{array}$ \\
\hline $\begin{array}{l}\text { Factor method } \\
\text { ISO 15686-2000 (2008) }\end{array}$ & $\begin{array}{l}\text { Building components of a } \\
\text { single building or building } \\
\text { type }\end{array}$ & $\begin{array}{l}\text { Factors yet to be defined } \\
\text { (based on experience) }\end{array}$ & $\begin{array}{l}\text { Budgeting without on- } \\
\text { site assessment }\end{array}$ \\
\hline $\begin{array}{l}\text { Stratus/Spectus (2012) } \\
\text { (based on method Schroeder) }\end{array}$ & $\begin{array}{l}\text { Portfolio management, } \\
\text { maintenance and refurbish- } \\
\text { ment, energy and others }\end{array}$ & $\begin{array}{l}\text { Not detailed enough for re- } \\
\text { furbishment design }\end{array}$ & $\begin{array}{l}\text { Strategic portfolio man- } \\
\text { agement incl. adjacent } \\
\text { functions like energy } \\
\text { certificate }\end{array}$ \\
\hline $\begin{array}{l}\text { EPIQR (based on EU research } \\
\text { project and IP Bau) (2012) } \\
\text { www.epiqr.de }\end{array}$ & $\begin{array}{l}\text { Single building, includes } \\
\text { portfolio functions and en- } \\
\text { ergy flow chart }\end{array}$ & $\begin{array}{l}\text { Requires measuring of area } \\
\text { and age of about } 50 \text { ele- } \\
\text { ments }\end{array}$ & $\begin{array}{l}\text { Analytical calculation of } \\
\text { maintenance budgets, } \\
\text { includes sustainability } \\
\text { criteria }\end{array}$ \\
\hline $\begin{array}{l}\text { TOBUS (based on EPIQR) } \\
\text { Caccavelli and Gugerli (2002) }\end{array}$ & $\begin{array}{l}\text { Single building, includes } \\
\text { energy flow chart }\end{array}$ & $\begin{array}{l}\text { Commercial buildings, re- } \\
\text { quires measuring of area } \\
\text { and quality of elements }\end{array}$ & $\begin{array}{l}\text { Analytical calculation of } \\
\text { maintenance budgets }\end{array}$ \\
\hline $\begin{array}{l}\text { INVESTIMMO (based on } \\
\text { EPIQR) } \\
\text { Caccavelli (2004) }\end{array}$ & $\begin{array}{l}\text { Portfolio management, in- } \\
\text { vestment decision support }\end{array}$ & Planning 12 years ahead & $\begin{array}{l}\text { Portfolio analysis using } \\
\text { different criteria }\end{array}$ \\
\hline $\begin{array}{l}\text { DUEGA (based on IP Bau } \\
\text { 1991, 1995) } \\
\text { Gredig et al. (1997) }\end{array}$ & & Not supported anymore & $\mathrm{n} / \mathrm{a}$ \\
\hline $\begin{array}{l}\text { SUREURO (2005) } \\
\text { www.sureuro.com (website } \\
\text { not updated since 2005) }\end{array}$ & $\begin{array}{l}\text { Includes aspects of sustaina- } \\
\text { bility and user participation }\end{array}$ & Residential buildings & $\mathrm{n} / \mathrm{a}$ \\
\hline $\begin{array}{l}\text { Building diagnosis } \\
\text { idi-al (2012) } \\
\text { www.bakaberlin.de }\end{array}$ & Single building of any type & $\begin{array}{l}\text { Certified assessors neces- } \\
\text { sary }\end{array}$ & $\begin{array}{l}\text { Detailed analysis result- } \\
\text { ing in a refurbishment } \\
\text { design proposal with al- } \\
\text { ternatives }\end{array}$ \\
\hline $\begin{array}{l}\text { Maintenance management } \\
\text { systems MMS (different prod- } \\
\text { ucts available on the market, } \\
\text { e.g. Maximo, visualFM, etc.) }\end{array}$ & $\begin{array}{l}\text { Systems and elements with } \\
\text { fixed periodical maintenance } \\
\text { intervals based on technical } \\
\text { life time of elements }\end{array}$ & $\begin{array}{l}\text { Requires extensive data } \\
\text { management; not suitable } \\
\text { for building elements due to } \\
\text { the large amount of equal } \\
\text { elements (e.g. doors, walls) } \\
\text { and little periodical mainte- } \\
\text { nance activity performed on } \\
\text { them. }\end{array}$ & $\begin{array}{l}\text { Mainly used for impor- } \\
\text { tant or costly technical } \\
\text { equipment requiring } \\
\text { regular maintenance in- } \\
\text { tervals }\end{array}$ \\
\hline $\begin{array}{l}\text { Mathematical methods for } \\
\text { industrial maintenance e.g. in } \\
\text { Percy and Kobbacy (2000) }\end{array}$ & $\begin{array}{l}\text { Preventive maintenance in } \\
\text { industrial production facili- } \\
\text { ties }\end{array}$ & $\begin{array}{l}\text { Less suitable for longer } \\
\text { maintenance intervals in } \\
\text { buildings, complexity of } \\
\text { models }\end{array}$ & $\begin{array}{l}\text { Mainly used for techni- } \\
\text { cal equipment requiring } \\
\text { regular maintenance } \\
\text { intervals }\end{array}$ \\
\hline
\end{tabular}




\subsection{Questionnaire}

65 portfolio managers who all use Stratus/Spectus were asked for permission to use their data for scientific research. A total of 24 gave a positive response and 18 (28\%) additionally answered a questionnaire (Annex 3) on their usage and opinion of the software Stratus/Spectus. 94\% of the 18 respondents manage all, or the large majority, of their buildings with the system (question 1). 78\% regularly update the building condition data following construction or refurbishment projects (question 2). $39 \%$ differentiate between regular maintenance expenses and investments in refurbishment by applying a fixed threshold value. This value varies considerably between 5'000 and 300'000 CHF. For almost $50 \%$ this differentiation does not seem required (question 3). 50\% have checked the fit of the real expenses with the prognosis and agree partly or fully with the results of the software. As a part of this group, 17\% have developed a factor of their own to correct the prognosis for their budgeting purposes. There is no clear tendency towards an overly high or an overly low prognosis visible (question 4). 34\% have set themselves a goal for the overall condition of their portfolio. These goals are all between $75 \%$ and $85 \%$ for $C_{t}$ (question 5 ). $44 \%$ revalidate their portfolio about every five years (question 6). In short summary, the system is neither used in a uniform way nor in the same depths by the respondents. The answers to questions 3 and 4 especially raise some questions and highlight the need for further research (see chapter 5).

\subsection{Comparison with effective data of 60 buildings - maintenance signature}

The Swiss Federal Institute of Technology in Lausanne (école polytechnique fédéral de Laus- anne EPFL) has introduced a comprehensive scheme of building cost monitoring and controlling called INDIANA (INDIcateurs ANAlytiques) wherein figures for maintenance and refurbishment are collected and presented separately. The figures are published annually, the latest in Chatton et al. (2011).

The level of detail enables the drawing of the maintenance and refurbishment signatures of the 60 buildings of the EPFL. The concept of the signatures is derived from the known energy signatures e.g. used to calculate energy savings in Zmeureanu (1990). The maintenance and refurbishment signature offers possibly a new way to analyse maintenance costs. The aim is to extract certain patterns from measured data like the dependency of maintenance expenses on condition $C_{t}$, and to distinguish between maintenance and refurbishment costs independently from individual accounting practices.

The effective expenses in the EPFL portfolio as shown in Figure 5 have been compared with the results from Stratus/Spectus. Adding maintenance and the constant base of refurbishment (averaged over 3 years) together, a figure of around 1.0\% of the reinstatement value for regular maintenance is achieved. This is very close to the recommendation of Stratus for this portfolio. Against the assumptions in the instrument, the effective figures for these 60 buildings show a constant level of maintenance, irrespective of the condition $C_{t}$. A possible explanation for this could be the high level of installed building technique that requires a constant level of maintenance activities and the planned maintenance schemes (the level of installed building technique is already a criteria in Stratus to characterize a given building influencing the cost split of building elements). The investments in
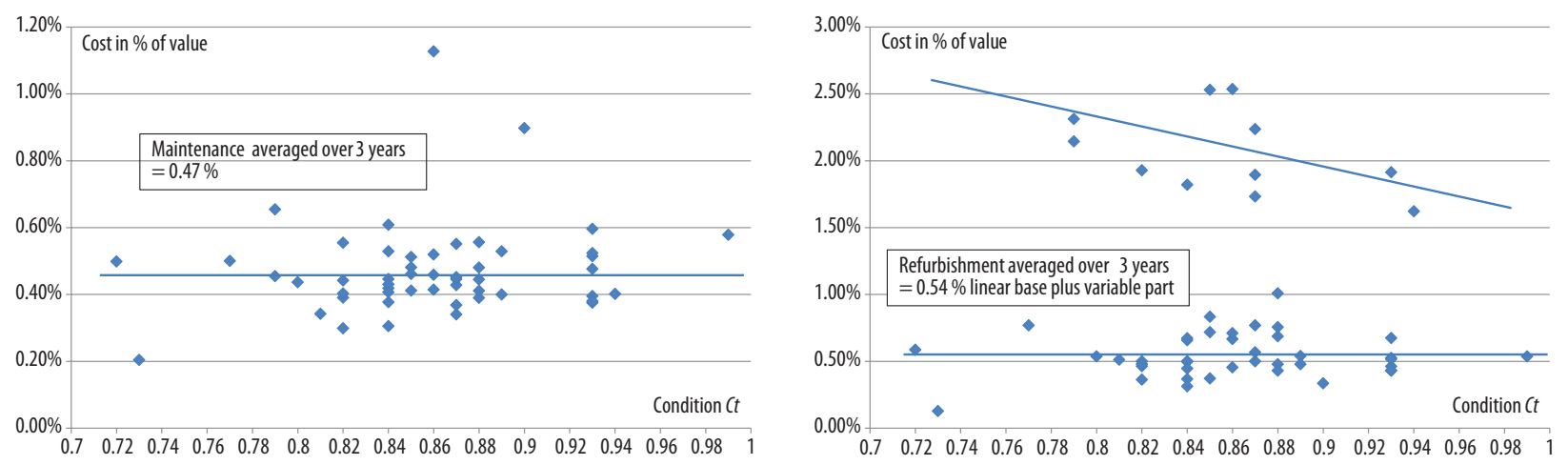

Fig. 5. The maintenance and the refurbishment signatures of the 60 buildings of the EPFL showing average annual costs in percentage of the building reinstatement values over the 3 years period from 2008 to 2010 in function of the building condition $C_{t}$ according to Stratus (Note: the buildings form part of the portfolio shown in Figure 3 ) 
refurbishment during this three year period were found not to be representative in the long-term due to a prevailing program for new construction.

\subsection{Comparison with effective data of 17 buildings}

The study of Bahr and Lennerts (2010) is the only one known that provides effective and comparable cost data in this field over several decades. Therefore, a desktop simulation of these 17 buildings (see Annex 2) has been performed on Stratus/ Spectus.

The comparison of the results from the detailed analysis of the maintenance and refurbishment costs of the 17 buildings analysed by Bahr and Lennerts with the results from the desktop simulation of this portfolio is shown in Figure 6. The simulation was performed by using the default values in the software tool for 17 virtual buildings of the same type, size and age (all construction dates set at $t=0$ as in Bahr und Lennerts). It shows a nearly identical sum of total costs over 45 years. The total average costs are around $2.2 \%$ per annum with a total difference of only $5 \%$ over this lengthy period. Additionally, both curves show some equal trends in the distribution of the costs over this long-term period. Maintenance rises slowly during the first 30 years in both curves. The first replacement of technical building installations (e.g. heating system, sanitary equipment) happened earlier in the effective portfolio than estimated in Stratus/Spectus. This could be due to the construction dates between 1950 and 1980 and the following rapid changes in standards, technology and requirements. Refurbishment works in the effective portfolio are mainly spread over the period of about 30-35 years while the desktop simulation shows distinct peaks for the different building elements according to their assumed durability. The data of the 17 buildings in detail shows more dispersed and partly even larger peaks. The peaks in the calculation of real buildings may differ from the desktop simulation due to the corrections resulting from the on-site assessment of the actual conditions of elements.

In summary, it has been possible to simulate the total maintenance and refurbishment costs of a real portfolio of 17 well researched buildings with astonishingly high accuracy in regards to the total amount of investments while the distribution of major refurbishments works over 45 years shows some differences. In practice, these may be influenced by strategic decisions and amended through periodic on-site assessments. The differences are also put into perspective by the fact that maintenance is not usually planned more than 5 years ahead of time.

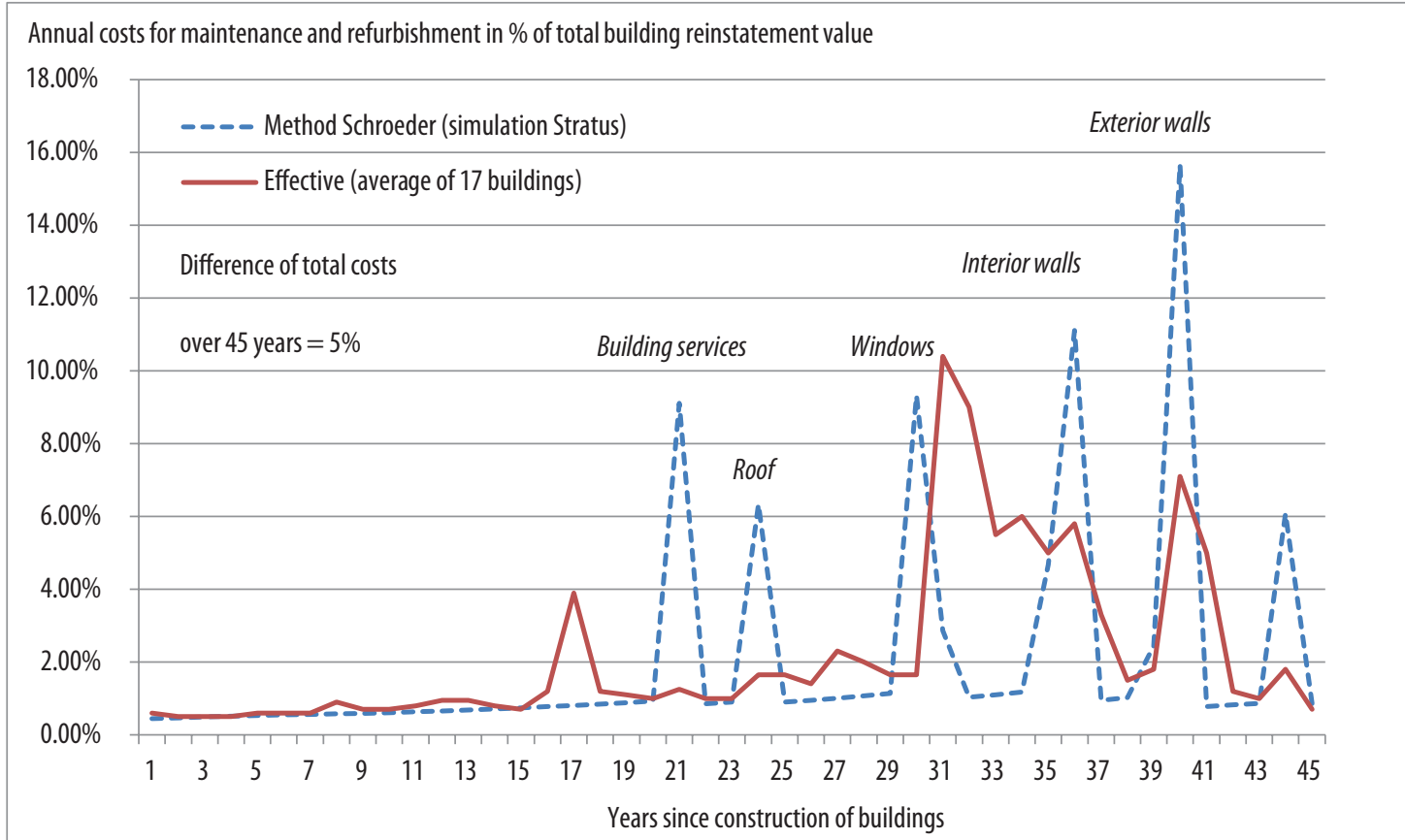

Fig. 6. Comparison of the maintenance and refurbishment costs of 17 buildings analysed in detail by Bahr and Lennerts with a desktop simulation using Stratus/Spectus over a period of 45 years (in Italic: indication of elements causing the distinct peaks in the theoretical simulation) 


\section{CONCLUSIONS}

Maintenance and refurbishment budgeting is not only a technical question but also contains strategic aspects like financial considerations and the need to consider changes in user requirements, market condition and the legal framework. As such, any method to calculate and justify these budgets must be transparent and credible as well as open for strategic considerations.

The method Schroeder implemented in the software Stratus/Spectus has proven itself as a cost efficient, easy-to-use and credible method to support strategic maintenance and refurbishment decisions in property management and to justify the necessary budgets. One limitation is that it is not intended to calculate detailed construction costs of a refurbishment project.

Some of its advantages over most other methods in this field are:

- It is applicable for all types of buildings and can therefore be used for heterogenous/mixed portfolios.

- It is cost efficient to operate as it requires very little input data that is easy to maintain because annual deterioration is calculated automatically.

- It enables a dynamic simulation of the effects of maintenance expenses and refurbishment investments on the condition of a single building or a whole portfolio in the long-term.

Nine assumptions behind the method Schroeder have been evaluated. Five assumptions have been verified. The remaining four are based on empirical evidence and likely sufficient for strategic budgeting, but more research would be needed for validation. The method has also been rated against other methods in this field and out of this rating a possible explanation for its success was extracted. A direct comparison of these methods would require more criteria and is only partially possible because many of those methods have a different focus. The method was originally designed to accurately simulate a given large portfolio. The comparison of simulated budgets with effective cost data of two different portfolios where data was available has found a close match too. This finding is valid for these three portfolios only. The questionnaire amongst users has shown that the standard values used in the application are not equally valid for all portfolios. Different cost calculations (e.g. threshold for maintenance) and characteristics of buildings and portfolios may be the reasons for this. Some of the factors influencing the costs are described in Bahr and Lennerts (2010) or Lavy and Shohet (2007). Caccavelli (2004) mentions 34 cost influencing factors of which the method Schroeder considers only a few. This does not seem to keep portfolio managers from using the method possibly due to other benefits like condition monitoring.

\section{FURTHER RESEARCH}

In the field of building maintenance and refurbishment there is only little reliable and comparable long-term data available to confirm any such budgeting method so more research is still needed. There is no general agreement in literature about the proper level of maintenance expenses and refurbishment investments, e.g. expressed as a percentage of the reinstatement value. The new definitions in the EN 15221-4 or the proposed maintenance and refurbishment signatures may help to standardise cost data collection in order to get a better understanding of the long-term behaviour of the system "building portfolio". For example, the assumption of condition dependent maintenance expenses could have only been verified in one of the two real portfolios where effective data was available. The other one shows a linear distribution. These behaviours are yet to be explained. Another question is if all major cost influencing factors have been considered in the method or if more variables are needed to cover portfolios with specific characteristics.

How the method and its assumptions and parameters can be adapted to different property markets other than those in central Europe also requires further research. The focus of such research should be on the influence of different climatic conditions or different construction standards on the service-life of building elements to adapt the depreciation curves. However, there is no obvious reason why the method itself could not be applied universally.

\section{REFERENCES}

Bahr, C.; Lennerts, K. 2010. Quantitative validation of budgeting methods and suggestion of a new calculation method for the determination of maintenance costs, Journal of Facilities Management 8(1): 47-63 http://dx.doi.org/10.1108/14725961011019076

Bjørberg, S. 2008. Public buildings - from decay to model of excellence, Norwegian University of Science and Technology Trondheim and Multiconsult AS. Available at: www.metamorfose.ntnu.no/Artikler/SveinBjorberg2009/From_decay_to_Model_of_Excellence.pdf [accessed 21 March 2012] 
British Standard BS 7543:1992 Guide to durability of buildings and building elements, products and components. 1992.

Caccavelli, D.; Gugerli, H. 2002. TOBUS - A European diagnosis and decision making tool for office building upgrading, Energy \& Buildings 34(2): 113-119. http://dx.doi.org/10.1016/S0378-7788(01)00100-1

Caccavelli, D.; Balaras, C.; Bauer, M.; Lawrence, R.; Hansen, K.; Franco, G.; Wetzel, C.; Flourentzou, F. 2003. A decision-making tool for long-term efficient investment strategies, in Proceedings of the $2^{\text {nd }}$ international symposium ILCDES 2003: Integrated Lifetime Engineering of Buildings and Civil Infrastructures, 1-3 December 2003, Rotterdam, Netherlands, 1001-1006.

Caccavelli, D. 2004. INVESTIMMO - a decision-making tool for long-term efficient investment strategies in housing maintenance and refurbishment, Final Technical Report, Centre Scientifique et Technique du Bâtiment (CSTB), Département Dévelopement Durable, Paris.

Chatton, I.; Moszczynski, J.; Pichon, P. 2011. Indicateurs analytiques domaine immobilier - EPFL DII. Rapport annuel - exercice 2010 [Annual report 2010 of real estate indicators], Ecole polytechnique fédéral de Lausanne EPFL. ISBN 978-2-9700649-2-3 (In French)

Christen, M.; Girmscheid, G.; Wallbaum, H. 2011. Application of industrial maintenance methods on building maintenance, in Modern methods and advances in structural engineering and construction. Research Publishing Services. ISBN 987-981-08-7920-4

EPIQR 2012. Software application, CalCon Deutschland $A G$. Available at: www.epiqr.de [accessed December 2012]

European Standard EN 15221-4:2012 Taxonomy, classification and structures in facility management. 2012.

Graf, P. 2008. Bauteilkosten in Bezug auf den Gebäudeneuwert: eine sammlung von Kostenkennwerten [Cost of building elements as a portion of total building costs: a collection of cost indicators]. Basler \& Hofmann AG, Ingenieure, Planer und Berater. ISBN 978-3-033-01735-1 (In German)

Gredig, J.; Rüst, B.; Wright, M. 1997. Diagnosemethode für die Unterhalts- und Erneuerungsplanung verschiedener Gebäudearten, Schlussbericht Forschungsprojekt. Zentralschweizerisches Technikum Luzern, Ingenieurschule HTL, Pfäffikon.

idi-al. 2012. Software application, Bundesarbeitskreis Altbauerneuerung e.V., Berlin. Available at: www. bakaberlin.de [accessed December 2012]

International Standard ISO 15686:2008 Buildings and constructed assets - Service life planning. 2008.
IP Bau 1991. Alterungsverhalten von Bauteilen und Unterhaltskosten [Deterioration of building elements and maintenance costs], Bundesamt für Konjunkturfragen, EDMZ, No. 724.441 d. (In German)

IP Bau 1995. Grobdiagnose Zustandserfassung und Kostenschätzung von Gebäuden [Analysis of condition and estimation of refurbishment costs of buildings], Bundesamt für Konjunkturfragen, EDMZ, No. 724.431 d. (In German)

Kohler, N.; Yang, W. 2007. Long-term management of building stocks, Building Research \& Information 35(4): 351-362. http://dx.doi. org/10.1080/09613210701308962

Kumar, D.; Setunge, S.; Patnaikuni, I. 2010. Prediction of life-cycle expenditure for different categories of council buildings, Journal of Performance of Constructed Facilities 24(6): 556-561. http://dx.doi. org/10.1061/(ASCE)CF.1943-5509.0000127

Lavy, S.; Shohet, I. 2007. On the effect of service life conditions on the maintenance costs of healthcare facilities, Journal of Construction Management and Economics 25: 1087-1098. http://dx.doi. org/10.1080/01446190701393034

Meyer-Meierling, P. 2011. Gesamtleitung von Bauten [Construction project management]. vdf Hochschulverlag an der ETH Zürich. ISBN 978-3-7281-3269-7 (In German)

Mickaityte, A.; Zavadskas, E. K.; Kaklauskas, A.; Tupenaite, L. 2008. The concept model of sustainable buildings refurbishment, International Journal of Strategic Property Management 12(1): 53-68. http:// dx.doi.org/10.3846/1648-715X.2008.12.53-68

Percy, D.; Kobbacy, K. 2000. Determining economical maintenance intervals, International Journal of Production Economics 67: 87-94. http://dx.doi. org/10.1016/S0925-5273(00)00013-X

Schroeder, J. 1989. Zustandsbewertung grosser Gebäudebestände [Condition assessment of large building portfolios], Schweizer Ingenieur und Architekt 107(17): 449-459. (In German)

Spectus/Stratus 2012. Software application, Basler \& Hofmann AG; Ingenieure, Planer und Berater. Available at: www.stratusimmo.ch or www.spectusimmo.com [accessed March 2012] (English version in preparation).

SUREURO 2005. Available at: www.sureuro.com, website not updated since 2005 [accessed March 2012]

Zavadskas, E. K.; Kaklauskas, A.; Raslanas, S. 2004. Evaluation of investments into housing renovation, International Journal of Strategic Property Management 8(3): 177-190.

Zmeureanu, R. 1990. Assessment of the energy savings due to the building retrofit, Building and Environment 25(2): 95-103. http://dx.doi.org/10.1016/03601323(90)90020-R 


\section{ANNEX 1}

Table of building elements used in the practical software application of the method Schroeder (Stratus/ Spectus)

\begin{tabular}{lllll}
\hline No. & Element & Specification & $\begin{array}{l}\text { Expected service } \\
\text { life in years }\end{array}$ & $\begin{array}{l}\text { Portion of total } \\
\text { building costs in \% }{ }^{1)}\end{array}$ \\
\hline 1 & Load-bearing structure & light weight - massive & $75-120$ & 35 \\
2 & Pitched roof & type of roof covering & $40-50$ & 4 \\
4 & Flat roof & type of roof covering & $25-30$ & 4 \\
5 & Exterior walls, Facade & type of material & $40-55$ & 8 \\
6 & Windows & type of material, shading & $30-40$ & 8 \\
7 & Heat production & primary energy & $15-25$ & 2 \\
8 & Heat distribution & type of radiators & $15-25$ & 6 \\
9 & Sanitary facilities & cold, warm, wastewater & $15-25$ & 6 \\
10 & Electrical system & lightning and machines & $15-25$ & 3 \\
11 & Other building services & e.g. lifts & $15-25$ & 23 \\
12 & Interior walls and fittings & - & $20-30$ & - \\
13 & Other interior fittings & - & - & - \\
$14-20$ & Disponible & - & & \\
\hline
\end{tabular}

1) Proposed standard values, depending on type of building and specification.

\section{ANNEX 2}

Table of the 17 buildings simulated in Stratus

\begin{tabular}{|c|c|c|c|c|c|}
\hline \multicolumn{6}{|c|}{ Scope of work: Comparison of methods Stratus / Bahr } \\
\hline \multicolumn{6}{|c|}{ Data Bahr: 6 office buildings, 11 school buildings } \\
\hline \multirow[t]{2}{*}{ Building } & \multirow[t]{2}{*}{ Type of use } & \multirow[t]{2}{*}{$\begin{array}{l}\text { GFA } \\
\left(\mathrm{m}^{2}\right)\end{array}$} & \multirow[t]{2}{*}{$\begin{array}{l}\text { Year of } \\
\text { construction }\end{array}$} & \multirow{2}{*}{$\begin{array}{l}\text { Technoglogy } \\
\text { level (\%) }\end{array}$} & $\begin{array}{l}\text { Envelope } \\
\text { / cubature } \\
\left(\mathrm{m}^{2} / \mathrm{m}^{3}\right)\end{array}$ \\
\hline & & & & & $\mathrm{E}$ \\
\hline AG FDS & Office & 1'913 & 1952 & 20 & 0.29 \\
\hline AG PF & Office & $4^{\prime} 424$ & 1958 & 26 & 0.45 \\
\hline AKS PF & School & $22 ' 835$ & 1950 & 30 & 0.25 \\
\hline GBS KA & School & 11 '950 & 1984 & 38 & 0.41 \\
\hline GS BA & School & 797 & 1960 & 11 & 0.42 \\
\hline GS BB & School & $14^{\prime} 523$ & 1980 & 38 & 0.45 \\
\hline GS BÜ & School & 829 & 1958 & 18 & 0.45 \\
\hline GS NE & School & 1'244 & 1958 & 7 & 0.49 \\
\hline HE SCW & School & $15^{\prime} 402$ & 1965 & 27 & 0.34 \\
\hline HSL SBW & School & 17'802 & 1963 & 24 & 0.40 \\
\hline LG FR & Office & $8^{\prime} 146$ & 1965 & 23 & 0.19 \\
\hline LG MA & Office & 16 '859 & 1970 & 23 & 0.16 \\
\hline LG OF & Office & $5^{\prime} 823$ & 1956 & 23 & 0.28 \\
\hline MORE HN & School & $9^{\prime} 960$ & 1979 & 24 & 0.41 \\
\hline RA BR & Office & $6^{\prime} 153$ & 1979 & 26 & 0.26 \\
\hline RWG BB & School & 7'897 & 1980 & 27 & 0.49 \\
\hline STLA ET & School & $16 ' 595$ & 1967 & 28 & 0.26 \\
\hline \multirow{2}{*}{\multicolumn{2}{|c|}{ GFA: Gross Floor Area }} & & $\min =$ & 7 & 0.16 \\
\hline & & & $\max =$ & 38 & 0.49 \\
\hline Source: & Bahr (2010) & & average $=$ & 22.5 & 0.325 \\
\hline
\end{tabular}




\section{ANNEX 3}

Questionnaire added to a letter asking portfolio managers for permission to use their Stratus data for scientific research (respondents: 27 out of 64; positive: 24; questionnaires: 18 ):

1. Ist das gesamte Portfolio in Stratus erfasst oder gibt es eine Erfassungsgrenze und wo liegt diese?

$E$ : Do you manage the complete portfolio with Stratus or is there a limit/threshold and what would this limit be?

Answers:

- All buildings $\quad 10$

- Nearly all buildings 7

- Majority of buildings 1

2. Welche baulichen Massnahmen werden in Ihrem Stratus regelmässig nachgetragen?

E: Which realised construction measures are being updated in Stratus on a regular basis?

Answers:

- None yet, but planned 1

- All projects 7

- All large projects 4

- Threshold dependent 2 (values from 3'000 to 50'000 CHF)

- Condition dependent 1

- None

3. Wie werden laufende Aufwendungen (Instandhaltung) und aktivierbare Investitionen (Instandsetzung) unterschieden (z.B. durch einem bestimmten Betrag)?

E: How are regular maintenance expenses and investments in refurbishment separated (e.g. based on certain amount of the bill)?

Answers:

- Based on a threshold $7 \quad$ (39\%); (values from 5'000 to 100 '000 CHF)

- Different budgets for each 2

- No differentiation made 2

- No suitable answer 5

- No answer

4. Stimmen die im Stratus prognostizierten Werte mit Ihren Ausgaben und Investitionen überein?
E: Do the prognosticated values for maintenance and refurbishment in Stratus correspond with the actual costs?

Answers:

- Yes

- Partly yes

- Applying a factor

- No

- Don,t know

- No suitable answer 1

*) Factors mentioned are: 0.8 and 1.25 for refurbishment, 1.5 for maintenance;

no correlation with answers to question 3 (threshold) was found.

5. Haben Sie ein Ziel für einen minimalen oder einen anzustrebenden Zustandswert des gesamten Portfolios oder für einzelne Gebäude oder Gebäudegruppen definiert?

E: Did you set goals for the condition to be achieved, either for the whole portfolio or for a group of buildings or individual buildings?

Answers:

- Yes, numerical 5

- Yes, qualitative

- Not yet

- No

- No suitable answer

6. Wie oft werden die Gebäude neu bewertet? Haben Sie dabei systematische Abweichungen zu den Prognosen in Stratus festgestellt? E: How often do you reassess the value of your buildings? Did you find systematic differences between the estimated values and the calculated values in Stratus?

Answers:

- Every ca. 10 years 1

- Every ca. 5 years 8

- Every ca. 2 years 4

- No 3

- No answer 2

7. Weitere Hinweise

E: Further comments?

Answers: 3 diverse comments e.g. inviting the authors to a personal discussion. 